\title{
MODERNIZATION OF EDUCATION IN THE LATE OTTOMAN EMPIRE
}

\section{Lathiful Khuluq}

A lecturer of UIN Sunan Kalijaga and Ph.D. student at McGill University, Canada.

الملخص

بيحث هذا الدقال حول ظاهرة تحديث أو أستخدام الاساليب الغربية في التعليم في الدولة العثمانية والذي كان فى أوجه في زمن "التنظبيات" في القرن التاسع

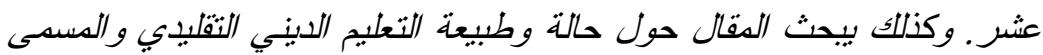
"مدرسة" أثناء بد/ية تعديم التحديث في التعليم وهذا الدوضوع بعتبر بداية البحث وكخلفية هذا البحث. بعد ذاللك نتطرق الباحث كذلك الى بعض اشكال الددارس التقليدية. وسرد الباحث بعض العوامل التي دفعت عملية التحديث في التعليم التي تتعلق بالحالة الرديئة التي كانت تعيشها الدولة العثمانية من الجو انب العسكرية و السياسية والاجتماعية وكنلك التعليم بصورة خاصة. وفي النهاية

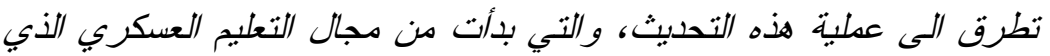
يعتبر كبرنامج مساعد في تطوير الدجال العسكري. بدأ تحديث التعليم الددني في لئي

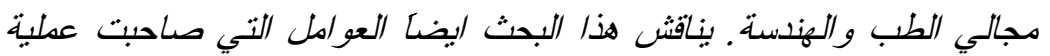
Abstrak التحديث أعلاه ، وكذلك العواهل التىى عرقلت هذه العطلية.

Artikel ini berbicara tentang fenomena modernisasi dan westernisasi pendidikan di Turki Usmani yang berpuncak pada era tanżimāt pada abad ke-19. Uraian tentang kondisi pendidikan agama tradisional yang dikenal dengan istilah medrese menjelang pemberlakuan program 
Lathiful Khuluq

modernisasi pendidikan mengawali tulisan ini sekaligus sebagai latar belakang tulisan ini secara keseluruban. Bagian ini juga membahas beberapa model lembaga pendidikan tradisional. Beberapa faktor pendorong modernisasi pendidikan dibahas di bagian selanjutnya, baik yang terkait dengan kondisi keterpurukan Turki Usmani dalam bidang militer, politik, sosial, maupun pendidikan itu sendiri. Bagian terakhir berbicara tentang proses modernisasi pendidikan di Turki Usmani, yang dimulai dari sektor militer sebagai program pendidikan untuk mendukung kebutuban pengembangan kemiliteran. Lembaga pendidikan sipil yang dibentuk pertama dalam kerangka modernisasi pendidikan antara lain adalah sekolah kesehatan dan teknik. Dalam bagian ini juga dibahas tentang hal-hal yang menyertai proses modernisasi tersebut, termasuk. faktor-faktor penghambatnya.

Keywords: modernization, tan₹imāt, medrese, education.

\section{A. Introduction}

The modernization of education in the Ottoman Empire was a project of long standing. The sultans Selim III (1789-1807) and Mahmud II (1808-1839) were among the earliest rulers to concern themselves with the matter, but it was during the Tanzimät era (18391876) that efforts at modernizing education reached a peak in the Empire, largely due to the work of intellectual and political figures such as Mustafa Resit Pasa (d. 1858), Ali Pasa (d. 1871) and Fuat Pasa (d. 1869), under the protection of Sultan Abdülmecit I (1839-1861). The modernization trend continued during the reign of Sultan Abdülhamid II (1876-1908/9), but here more emphasis was placed on Islamic morality and discipline.

The word Tanz̧imăt means "regulations" in Turkish. Many sectors of national development came in for regulation at this time, while a considerable number of Western-inspired political and social reforms were introduced in an effort to modernize the Ottoman Empire. Modernization in education specifically refers in this context to attempts at redesigning the educational system in the Empire so that it might be compatible with the state's priorities. Western advances, particularly in education, drove this effort at modernization. Thus, modernization 
could be seen as Westernization in education. To gain a clearer picture of the modernization that took place in the Ottoman Empire during the nineteenth century, it would be useful to glance first at the traditional system of education in place prior to this development. This will allow us to see the factors that triggered the modernization efforts as well as reveal the motives and aims behind it. In looking at the modernization process, the focus will be on the continuity of modernization. The constraints and impacts of modernization will also be explored in order to reveal the failures and successes of the process. Our survey of the background will begin with a review of religious education, which was the dominant form of schooling in the Empire in the period preceding the Tanzimàt era.

\section{B. Islamic Education}

Prior to the nineteenth century, the educational institutions in the Ottoman Empire were mainly religious. Students were taught the Islamic sciences and languages. Practical knowledge was rarely taught in school: students had to acquire practical skills in their spare time from their parents or in the workplace through the guild system. For most Muslims, the only accessible schools were Qur'an-schools, namely the mahalle mektebi or sibyan mektebi (children's school) or ibtida'i schools. For those who had the talent, they could continue their studies at medreses, the most basic of which could be found in provincial towns and the most advanced in Istanbul. At this level, the student was on the way to becoming an expert in the Islamic sciences. ${ }^{1}$ The first Ottoman medrese was established in Iznik in 1331 in a former church building, and was run by Daud of Kayseri, one of the most famous scholars of the time. Other religious schools were developed throughout the Ottoman Empire in order to enhance the religious knowledge of the Muslim population as well as to strengthen people's loyalty to the sultan. To manage these schools, the authorities invited knowledgeable scholars from various parts of the Muslim world, among them 'Alā' al-Din of Tus (d. 1482).

${ }^{1}$ Selcuk Aksin Somel, "Ottoman Islamic Education in the Balkan in the Nineteenth Century”, Islamic Studies 36:2, 3 (1997), p. 442. 
Another, less formal place to acquire Islamic knowledge was the Sufi lodge (zawiyah) where tariga rituals and basic Islamic teachings were taught and practiced. In addition, during the formative period of Ottoman culture (fourteenth and fifteenth centuries), many Ottoman ulema traveled under the sponsorship of various individuals and charitable foundations to famous centers of learning in Egypt and Persia, where they studied the Islamic sciences such as Qur'anic exegesis and jurisprudence. They were mainly attracted to famous scholars in those areas. ${ }^{2}$ At the top of the learning hierarchy were the members of the sultan's household, for whom the Sublime Porte provided special tutors. The main aim of their education was to instill loyalty and obedience to the sultan, but in the process they also learnt the Islamic sciences, Ottoman, Persian, and Arabic literature, history, music, math, and physical and vocational training. ${ }^{3}$

A more rapid development in religious education occurred with the accession to power of Sultan Mehmed the Conqueror (1451-1481), ${ }^{4}$ who established several medreses to compensate for a lack of trained ulema in the Empire. After the conquest of Constantinople, he converted eight churches into medreses, assigning to each of these schools a famous scholar as director. He also established medreses called the Sahn-i Seman or the Semaniye, each of which was also placed in the hands of a scholar. These medreses were attached to his Great Mosque, and consisted of elementary and secondary levels. In addition to generous classroom space, each had an endowed library and a separate general library. One student was usually selected to become the assistant of the teachers; bearing the title of muderris, he was responsible for repeating lessons with the students and supervising their discipline. All students benefited from endowed scholarships. The Semaniye medrese eventually became the highest-ranking educational institution in the

${ }^{2}$ Halil Inalcik, The Ottoman Empire. The Classical Age 1300-1600, Trans. Norman Itzkowitz and Colin Imber (London: Weidenfeld and Nicolson, 1973), p. 166.

${ }^{3}$ Fatma Müge $G$ cek, Rise of the Bourgeoisie, Demise of Empire. Ottoman Westernization and Social Change (New York and Oxford: Oxford University Press, 1996), p. 24.

${ }^{4}$ For this sultan, see Franz Babinger, Mebmed The Conqueror and His Time, trans. Ralph Manhein (Princeton, N.J.: Princeton University Press, 1978). 
Empire, even higher than the Dār al-hadis established by Murad II (1421-44 and 1446-51) in Edirne and another medrese in Bursa. ${ }^{5}$

At the higher levels of religious education, students were taught rhetoric, philosophy, languages and the Islamic sciences. Some students were able to continue their studies, especially in Islamic jurisprudence and theology. Success in this discipline could lead to a promising career as a member of the learned class, whether as 'allim, mufti, judge, or professor. ${ }^{6}$

The development of religious education gathered speed under Sultan Suleyman the Magnificent (1520-1566). ${ }^{7}$ During his reign, there were established four general and two specialized medreses at the highest level yet. The subjects taught in these institutions ranged from the science of prophetic tradition to that of medicine. ${ }^{8}$ Following the practice of his predecessors, Suleyman attached these medreses to his Great Mosque, which he intended to be a center of learning in the Islamic world. He also established schools for training Islamic scholars and judges. ${ }^{9}$ In the mosque complex, a hospital and medical college, equipped with a library, were established. ${ }^{10}$ Founded in 1556, this first medical school in the Empire was intended to offset the shortage of medical doctors in the Empire: the Sultan was in particular need of doctors to support his armies who were engaged in conflict far from the capital. ${ }^{11}$ However, the curriculum of the medical school in the Suleymaniye Medrese still concentrated on medical knowledge and practices based on the teachings of Galen and Avicenna. ${ }^{12}$

${ }^{5}$ Inalcik, The Ottoman Empire, p. 167.

${ }^{6}$ Justin McCarthy, The Ottoman Turks. An Introductory History to 1923 (New York: Addison Wesley Longman, 1997), p. 120.

${ }^{7}$ For this figure, see Albert Howe Lyber, The Government of the Ottoman Empire in the Time of Suleiman the Magnificent (Cambridge: Harvard University Press, 1913).

${ }^{8}$ Inalcik, The Ottoman Empire, p. 169.

${ }^{9}$ Justin McCarthy, The Ottoman Turks, p. 70-71.

${ }^{10}$ McCarthy, The Ottoman Turks, p. 93.

${ }^{11}$ Tuncay Zorlu, "The Medical Medrese of Süleymaniye," in Ali Caksu, International Congress on Learning and Education in the Ottoman World (Istanbul: IRCICA, 2001), p.64.

${ }^{12}$ Bernard Lewis, The Emergence of Modern Turkey (London, New York, Toronto: Oxford University Press, 1961), p. 83. 
The budget of a medrese at the time could come from one or more of a number of sources. The sultan and other bureaucrats, as well as the wealthy, contributed as individuals to support the institution. Endowments from the sultan and his viziers were often given for schools in major cities and other parts of the Empire. Pious local merchants and governors also participated in building smaller mosques and schools in provincial cities. The endowment usually provided for the tuition fees of students and salaries for some teachers. The charitable foundation (vakif) was usually attached to a mosque, hospice or some other charitable institution. ${ }^{13}$ Hence the Sublime Porte as an institution did not finance these religious schools: it only supported then indirectly by not taxing the charitable foundations that managed them. It also paid the salaries of most of the ulema. In addition, some foundations were sustained by ongoing economic activities. For example, Mehmed the Conqueror built bazaars and shops whose income was dedicated to supporting the expenses of mosques and medreses. ${ }^{14}$

There were two kinds of medrese: the exterior medrese (khärij) and the interior medrese (däkbil). The exterior medrese provided lessons in the 'Fundamentals of Knowledge' (Arabic and the intellectual sciences). These medreses operated at various levels. At the primary level, students were taught basic Arabic grammar and syntax, logic, scholastic theology, astronomy, geometry and rhetoric. At progressively higher levels - usually available only in the main provincial citiesthey were taught rhetoric and the literary sciences. The highest-level medreses were the 'medrese of forty' and the 'medrese of fifty' (named after amount of the salaries paid to the teachers), which were established by princes, ladies of the royal family, or viziers. In these, students were taught the interpretation of a work of rhetoric and followed an intermediate course in scholastic theology and a higher course in jurisprudence. ${ }^{15}$

The interior medreses provided 'Higher Knowledge' in the religious sciences and were also graded. At the elementary level, students were taught the Hidaya. At the intermediate level, they were taught the

\footnotetext{
${ }^{13}$ Inalcik, The Ottoman Empire, p. 169.

${ }^{14}$ McCarthy, The Ottoman Turks, p. 116-117.

${ }^{15}$ Inalcik, The Ottoman Empire, p. 168.
} 
principles of jurisprudence from al-Taftazāni’s Talwīh. At the advanced level, they were taught Qur'ānic exegesis through al-Zamakhsharì's Kashshäf. A yet higher level of teaching could be found in Mehmed's eight preparatory medreses. Here, students received a specialized training in Islamic jurisprudence, Qur'anic exegesis, scholastic theology, rhetoric and other related studies. ${ }^{16}$

However, as early as the sixteenth century the quality of these religious schools began to go into decline. Internal disorder, high taxes and recurrent confiscation of the properties of rich individuals contributed to their disintegration. In order to avoid taxation and confiscation, the rich converted their properties into religious charities while employing their families in these educational activities regardless their religious knowledge. Pious foundations therefore came to be seen as only a means of preserving money, and little or no concern was felt for the quality of education. As a result, illiteracy among students, even after ten years of instruction, was a common phenomenon. ${ }^{17}$ The decline also occurred at the highest level of education, in the medreses. At the time, most ulema did not have the good, classical liberal education that their predecessors in the medieval Islamic period could boast. ${ }^{18}$ This decline was further aggravated by pride in past achievements, combined with suspicion and fear of contact with the infidel Western world, which had made advances in the development of education. Memorization of Qur'ānic verses and classical books written by medieval Muslim scholars became the principal aim of religious education. One $19^{\text {th }}$ century graduate of this system, mer Seyfeddin, wrote of his own experience in the medrese educational system: "We were forty youngsters in the school.... We had no division into grades. In chorus we learned the alphabet and text from the Koran, in chorus we learned the multiplication table by repetition, in chorus we chanted the prayers. So, all our lessons went along in an endless learning by rote of things, the meaning of which we were never able to

\footnotetext{
${ }^{16}$ Ibid., p. 169.

${ }^{17}$ Somel, "Ottoman Islamic Education", p. 443.

${ }^{18}$ Roderic H. Davison, Essays in Ottoman and Turkish History, 1774-1923: The Impact of the West (Austin: University of Texas Press, 1990), p. 166.
} 
comprehend."19

Apart from stagnated teaching methods, other weaknesses emerged in religious schools. In the first place, education was only provided to males before reforms were later introduced. The teachers in local schools were mostly local religious leaders or occasionally a traveling religious teacher. Sometimes, the subjects taught in these schools contained folk beliefs and the beliefs of mystical groups. Literacy was not the primary objective. Rarely did the curriculum produce bright students; ${ }^{20}$ indeed, it was for the most part irrelevant to industrial and technological needs. ${ }^{21}$ There were, of course, concerns expressed over the poor quality of schooling in the Ottoman Empire at the time. Most students had only learned the Qur'an by rote and a few letters of the alphabet by the age of eight or ten. They never acquired any Arabic or Persian or even formal instruction in Turkish, let alone arithmetic and geography. ${ }^{22}$

\section{The Impetus behind the Modernization of Education}

The advanced military power of the European nations put the Ottoman Empire on the defensive by the eighteenth century. In order to catch up, the Sublime Porte saw the need to modernize its educational system, particularly its military schools, by the end of this century. ${ }^{23}$ Several battles with Austria, Persia, and Russia had exhausted the military power of the Ottoman Empire. The Ottoman armies had been defeated in several battles since the seventeenth century. The crowning blow to Ottoman power, however, was the defeat of the Ottoman armies by Russia in 1877-78, as a result of which the Ottomans had to give up about 40 percent of its territory and about 20 percent of its

${ }^{19}$ Quoted in Davison, Essays in Ottoman, p. 172-3

${ }^{20}$ McCarthy, The Ottoman Turks, p. 276.

${ }^{21}$ Niyazi Berkes, The Development of Secularism in Turkey (Montreal: McGill University Press, 1964), p. 99.

${ }^{22}$ Carter V. Findley, Bureaucratic Reform in the Ottoman Empire. The Sublime Porte, 1789-1922 (Princeton, New Jersey: Princeton University Press, 1980), p. 125.

${ }^{23}$ Selcuk Aksin Somel, The Modernization of Public Education in the Ottoman Empire 1839-1908. Islamization, Autocracy and Discipline (Leiden, Boston, K ln: Brill, 2001), p. 15. 
population (about five and a half million people) at the Congress of Berlin on June 3, 1878. ${ }^{24}$ The event made Ottoman leaders realize the backwardness of Ottoman military technology. The need to develop the army led to the modernization of education in general, partly out of a need to enlighten the adult population and to build a new Ottoman army. ${ }^{25}$ The military backwardness of the Ottoman Empire was also mirrored by stagnation in other areas. As stated by Bernard Lewis, "while Europe swept forward in science and technology, the Ottomans were content to remain in their agriculture, their industry, and their transport, at the level of their medieval ancestors."26

The destruction of the Janissary army corps in 1826, which had previously opposed modernization, ${ }^{27}$ led to the acceleration of this modernization, ${ }^{28}$ and it was further accelerated by the ascendancy to political power of more radical politicians, who founded the Tansimat ${ }^{29}$ This regime opened wide the door of the Ottoman Empire to Western European influence for a period of about twenty years. Ottoman economic, political, legal and educational institutions were all modernized, to a greater or lesser degree, along the lines of Western European models.

Another boost to the modernization of education in the Ottoman Empire was the advancement of educational methods in western countries. The popular education movement had been in place in France and England since 1831. In Britain as a whole, schools were built in

${ }^{24}$ Martin Sicker, The Islamic World in Decline. From the Treaty of Karlowitz to the Disintegration of the Ottoman Empire (Westport, Connecticut, London: Praeger, 2001), p. 169.

${ }^{25}$ Berkes, The Development of Secularism, p. 101-102.

${ }^{26}$ Lewis, The Emergence of Modern Turkey, p. 27-32; Quoted in Andreas M. Kazamias, Education and the Quest for Modernity in Turkey (London: George Allen \& Unwin Ltd., 1966), p. 43-44.

${ }^{27}$ R. Murphy, "Yeni Ceri," in P.J. Bearman, Th. Bianquis, C.E. Bosworth, E. Van Donzel and W.P. Heinrichs (eds.), The Encyclopaedia of Islam, New Edition, Vol. XI (Leiden: Brill, 2001), p. 322-331.

${ }^{28}$ Berkes, The Development of Secularism, p. 138.

${ }^{29}$ Somel," Ottoman Islamic Education", p. 445. Tanz̧imat is the plural of the word tanzim which means ordering. Tanzimät means "a series of acts that would give a new order to the organization of the state." See, Berkes, The Development of Secularism, p. 144-5. 
such large numbers that even poor children had access to them, and there, as elsewhere, education flourished along with economic and technological advancement. Prussia had made elementary education compulsory as early as 1717 . As early as 1800 , almost 90 per cent of Scottish and 50 per cent of English males were literate, as were about two-thirds of French males at around the same period. By contrast, in the Ottoman Empire, only about 10 percent of the population was able to read. ${ }^{30}$ In addition, the educational system in Western countries, particularly in France and Britain, had produced new innovations in technology, which led to developments in other areas. Thus, Joseph Lancaster (1778-1838), a Quaker of modest origins, promoted education as a tool for producing responsible citizens who could exercise democratic liberties. He also promoted education for mass enlightenment and cultivation as well as popular secondary education. This movement gained popularity among the Greeks of Istanbul and later on among the Armenians. The American Protestant Mission, led by William Goodell, opened a Lancastrian school for Greek boys and, in the following year, for girls. ${ }^{31}$

Under the pressure of the Western powers, the Sultan was forced to give more freedom to non-Muslims in establishing their own schools. The weakness of the Ottoman armies also allowed European countries to intervene in the internal affairs of the Empire, particularly in matters affecting the non-Muslim minority population. This eventually led to the expansion of schools for non-Muslims in the Ottoman Empire, and these in turn put pressures on the central government to speed up its policy of expanding state education. ${ }^{32}$ The minority schools were patterned on Western models and offered instruction in subjects of a modern nature. This attracted many Muslims to western style schools - a development that the authorities saw as a threat to society. A further impetus to government action was the fact that such schools often strengthened the ethnic identities of local population, which led to the disaffection of many non-Muslim, non-Turkish Ottoman subjects, particularly in frontier areas. In order to win the hearts and

${ }^{30}$ McCarthy, The Ottoman Turks, p. 158.

${ }^{31}$ Berkes, The Development of Secularism, p. 102-103.

32 Somel," Ottoman Islamic Education", p. 445. 
minds of the population and to strengthen their loyalty to the Empire, the Sublime Porte decided at the beginning of nineteenth century to establish several western-style schools.

Hence, in order to prevent the undue spread of Western ideas, particularly those encouraging the independence of Ottoman territories in Europe, the Ottoman government had to compete with the westerntype minority schools. The Ottoman government was already familiar with the trend among minority groups to send their children to study in European countries, particularly Italy, ever since the sixteenth and seventeenth centuries. But now the graduates of western schools were establishing similar types of schools in the Ottoman Empire. For example, the Greeks established schools in the Peloponnese, Epirus and Western Anatolia, as well as on the Black Sea coast, Cyprus, and Crete. In these schools, students were exposed to Western scientific knowledge and its implementation. ${ }^{33}$

Numerous foreign schools, mostly operated by Christian missionaries, were likewise established in the Arab provinces and Eastern Europe, particularly for non-Muslims. By the eve of World War I, according to an unofficial survey, there were in the Ottoman Empire 500 French Catholic schools, 675 American schools, 178 British schools, and a lesser number of German, Italian, AustroHungarian and Russian schools. The French schools had a total enrollment of 59,414 students, the American 34,317, and the British 12,800 . Most of these schools were at the elementary level..$^{34}$ Once non-Muslim minorities were given the right to attend their own schools by the Islahat Fermāni of 1856, most parents chose to send their children to missionary or community schools designed along western lines. The Bulgarians, on the other hand, adopted the more secular pattern of Russian schools. ${ }^{35}$ The American school known as Robert

${ }^{33} \mathrm{G}$ cek, Rise of the Bourgeoisie, p. 115.

${ }^{34}$ Davison, Essays in Ottoman, p. 168.

${ }^{35}$ Diana Karabinova, "A Late Attempt to Find an Integrative Approach Through Common Secular Education: Midhat Pasa as Governor of the Danube Province (18641868)," in Ali Caksu, International Congress on Learning and Education in the Ottoman World (Istanbul: IRCICA, 2001), p. 240. p. 237-246. 
College was established in 1863 in Istanbul. ${ }^{36}$ Other educational institutions were founded by missionaries from Austria, France, England, Germany, and Italy. ${ }^{37}$ The missionary schools in particular, according to Salim Deringil, were perceived as the most serious and dangerous challenge to the future of the empire, as the school curriculum largely undermined the authority of the state. ${ }^{38}$

Concern over the potential for such schools to ferment local separatist activity led the central government to open its own schools in sensitive areas. For example, in order to prevent the spread of Greek nationalist sentiment among Albanians, the central government attempted in 1865 to establish modern Ottoman schools in areas such as Ergiri (Gjirokastër), Avlonya (Vlorë), Delvine and amlik ( ameria), although in the end only thirty Qur'an-schools were founded in order to guide local Muslims to the "path of civilization" and save them from the "darkness of ignorance." "The development of these religious schools instead of secular schools was in line with ideological change of government from the Tansimat to the Hamidian regime, which placed greater emphasis on Islamic morality. ${ }^{40}$

The initiative to establish modern schools often came from provincial governments and individuals. For example, Tạsin Efendi, an alumnus of the Civil Service School (Mekteb-i Mülkiye), took the initiative to teach mathematics and geography to students in certain Qur'an schools. A similar approach was taken by other administrators. Midhat Pasha, during his term as governor of the sancak of Nis (Ni ), established an industrial school of multi-ethnic and religious character in the area in $1862 .{ }^{41}$ He also reformed the existing Qur'an-schools of the region so that the graduates of these schools could continue to a

${ }^{36}$ See, Keith M. Greenwood, Robert College: The American Founders, (Istanbul: Bo azici University Press, 2000).

${ }^{37}$ Stanford J. Shaw and Ezel Kural Shaw, Reform, Revolution, and Republic: The Rise of Modern Turkey, 1808-1975 (Cambridge, London, New York, Melbourne: Cambridge University Press, 1977), p. 110.

${ }^{38}$ Deringil, The Well-Protected Domains, p. 112.

${ }^{39}$ Somel, The Modernization of Public Education, p. 72.

${ }^{40}$ See, Benjamin C. Fortna, Imperial Classroom: Islam, State, and Education in the Late Ottoman Empire (Oxford; New York: Oxford University Press, 2002).

${ }^{41}$ Somel, The Modernization of Public Education, p. 77. 
Rüsdiye school. He furthermore established several schools in Nis and Leskofça (Leskovac) and obliged all Muslim boys to enroll. When he became the governor of Danube (Tuna) province in 1864, he gradually established a network of reformed Qur'an and Rüsdiye schools in the province. Another of his measures was to introduce mixed-religious education in an attempt to reduce nationalist sentiment among Bulgarians, who often preferred to study in the Russian schools of Kisinau (Kisinev, Moldavia) and Odessa. His usage of local financial sources to support the development of education became an example to those who later drafted the Regulation of Public Education of $1869 .{ }^{42}$ Similar efforts on the part of local authorities and individuals were effective as well. For example, after the local council of Tekfurdagi (Tekirdag) sent a request to Istanbul to establish a Rüsdiye school in their area due to the growing economic strength of the local non-Muslim population, a school was immediately established in this area while plans to do the same in other areas were delayed as less urgent. ${ }^{43}$

A similar case occurred in Damascus. The modernization of Qur'an-schools and the establishment of Rüsdiye schools in Syria were driven by, among other reasons, the fact that the educational standard reached by Muslim children was lower than that of the non-Muslim population. This inequality led to disorder in Syria in 1860-61. People protested at the unequal social structure where many local Christians were better educated and socio-economically superior to the Muslims. The policy of mixed-religious education under the Tansima as unfair by many Muslims, since many non-Muslims already had access to Christian missionary educational institutions. ${ }^{44}$

Another motive for the modernization of education in the Ottoman Empire was the need to train new bureaucrats in practical and up-to-date knowledge so that the administration of the government could become more efficient. In addition, the development of education could boost social and economic development. ${ }^{45}$

\footnotetext{
${ }^{42}$ Ibid., p. 78.

${ }^{43}$ Ibid., p. 73.

${ }^{44}$ Ibid., p. 71.

${ }^{45}$ Ibid., p. 54.
} 


\section{The Modernization of Education}

The modernization of education was initially applied to higher education in the form of occupational schools. Attempts to establish modern secular schools had been made long before the Tanzimät period, mainly for military and bureaucratic training. As early as 1734, a school of mathematics (Hendesehane) had been established in the capital to provide engineers for the military. However, the school was closed soon afterwards. An effort was made in 1759 by Grand Vizier Ragib Pasa to reconstitute the school, which was then reestablished in 1784 by Halil Hamid Pasa who also brought Prussian and French advisors in order to secure the reforms of Selim III (1789-1807). ${ }^{46}$ A naval school and a military engineering school (Mühendishane) -both modern and secular - were also established in 1773 and 1793, respectively, mainly with the aid of European renegades. The Sublime Porte also established the School for Young Janissaries ('Ajemi Ogblanlari Mektebi). ${ }^{47}$ The curriculum of this military school consisted of instruction in "Turkish, Persian and Arabic languages... all manners of field sports such as riding, shooting with the bow, throwing the javelin and wrestling. Those who had fine voices and a bent for music also received musical instruction." ${ }^{48}$

In 1827, the program in naval engineering was separated from the School for Engineering (Mübendishane) to form a separate academy, which survived for a long time. The government then established more modern schools of military medicine and military theory, and opened as well civic schools aimed at public affairs, medicine, languages, and law. However, all these schools began at a quite elementary level. Of the 200 students attending the naval academy in the 1830s, half of them were just learning to read and write and only 30 of them were able to proceed further with their studies in navigation. ${ }^{49}$

\footnotetext{
${ }^{48}$ Alexander Pallis, In the Days of the Janissaries (London: Hutchinson and Co., 1951), p. 27.

${ }^{49}$ Davison, Essays in Ottoman, p. 170-1.
} 172.

${ }^{46}$ Merdin, The Genesis of Young Ottoman, p. 143.

${ }^{47}$ Somel," Ottoman Islamic Education", p. 442; Davison, Essays in Ottoman, p. 
In 1831-4, the Sultan also opened two other schools that served a military purpose: the Imperial Music School (Murika-i Humayun Mektebi) and the School of Military Sciences (Mekteb-i Ulum-i Harbiye). Some instructors from Europe were hired to teach in and manage these schools. However, as regular school graduates could not meet the basic requirements needed for admission into these schools, preparatory classes were established. ${ }^{50}$ The age-range of the students was flexible: there were students of forty and even fifty years old. Eventually, therefore, the number of students increased. The teaching in these academies was conducted in Turkish but the main text-books were in French. ${ }^{51}$ The earliest students in these schools were drawn from various ethnic backgrounds, some being converts to Islam taken from their families at a young age who had lost all identification with their families and early environment, so that their loyalty lay fully with the Sultan. Other instructors of the school were drawn not only from the ranks of the ulema but also from the Greek community. ${ }^{52}$ The schools thus managed to survive amid opposition and financial trouble.

In order to ensure the continued modernization of the schools, the Sublime Porte began in 1827 to send students abroad to study in European countries, despite opposition from Muslim clerics. This policy followed the precedent set by Muhammad Ali, the Ottoman governor of Egypt, who had sent individuals and groups of students to Paris in 1826. The Sublime Porte also sent students to England, France, Prussia and Austria in $1835 .{ }^{53}$ Husrev Pasa, who was in charge of modernizing the military, sent four students in 1830 from his own household, (sons of his servants or slaves), to study in Paris. After graduating, one later became a Grand Vizier, a second an artillery general, and a third a colonel of the General Staff. In the same year the Porte had also planned to send 150 students to study military science in Europe, but due to considerable opposition both from inside and outside the Palace, this plan was abandoned. Instead, in the following year (1831), a project was started to establish an Ottoman Military Academy which was

\footnotetext{
${ }^{50}$ Lewis, The Emergence, p. 83.

${ }^{51}$ Berkes, The Development of Secularism, p. 111.

${ }^{52}$ Pallis, In the Days of the Janissaries, p. 28.

${ }^{53}$ Berkes, The Development of Secularism, p. 111.
} 
realized three years later (1834). Several students were sent to Europe in the same year. Other groups departed for London, Paris, and Vienna in 1846, 1850, and in 1855. On their return, these students were given jobs teaching in the Military Academy. ${ }^{54}$

The first real civil medical and engineering schools were attached to the military school. Again, following the precedent of Muhammad Ali's medical school at the Abu Za'bal hospital in Cairo, the Sultan opened a medical school in Istanbul in 1827. As in other new schools, the medical school also established preparatory classes for those about to enter the faculty, where instruction was offered in either French or Turkish. The school was reorganized several times. ${ }^{55}$ Sultan Mahmud II also attempted to modernize traditional medical teaching by establishing a State Medical School, Tibhane-i Āmire in 1827, and another school for surgery (the Cerrabane) in 1828. These schools were reorganized in 1831. Some European physicians and younger men with some training in modern medical procedures, such as Sade de Gallière of France, were employed as professors in these institutions. General preparatory courses in anatomy, pathology, surgery, surgical chemistry, and military surgery formed the basic curriculum. Some graduates were sent to Europe to continue their studies, and they later became prominent physicians. ${ }^{56}$

Following the European model, the two medical schools were eventually integrated. A Turkish physician, Abdül-Hak Molla, was put in charge of reorganizing the new medical school, which reopened in 1838 as Dar-ul Ulüm-u Hikemiye ve Mekteb-i Tibbiye-i Sabane (Imperial School of Physical and Medical Sciences). A professor from Vienna, Karl Ambroso Bernard (1808-44), was invited to organize the curriculum. ${ }^{57}$ Here, Western medical knowledge was taught for the first time in the Empire. At the preparatory level, students were taught Arabic, French and religious knowledge, in addition to Turkish grammar

${ }^{54}$ Serif Merdin, The Genesis of Young Ottoman Thought. A Study in the Modernization of Turkish Political Ideas (Princeton, New Jersey: Princeton University Press, 1962), p. 212.

${ }^{55}$ Lewis, The Emergence, p. 82-83.

${ }^{56}$ Berkes, The Development of Secularism, p. 112.

${ }^{57}$ Ibid., p. 112. 
and Persian literature. However, after a further reorganization of the school, the courses in Arabic and religious knowledge were dropped in favor of increased instruction in French. The students were divided into those who knew French and those who did not, and the latter forced to take a course that gave them facility in this language. Persian literature was also dropped from the curriculum, while at the same time, European history and literature were added. ${ }^{58}$

At the opening ceremony for the medical school, Sultan Mahmud II encouraged students to study medicine directly from Western sources:

It is true that many books were written among us [Muslims] on medical sciences and that the Europeans even learned many things by translating these books into their own languages. The books were written in Arabic, however, and, as they ceased to be objects of interest and care in the Muslim schools for many years and as the number of men who knew them decreased, they became obsolete. To go back to these works now and plunge into their study in order to translate the science of medicine into our own language, Turkish, would be a painstaking job actually requiring many years. Having appropriated these works into their own languages, the Europeans have been busy improving upon them for more than a hundred years. In addition, they have facilitated the methods of teaching these subjects greatly and have added their new discoveries. Therefore, the Arabic works seem to me somewhat defective in comparison with these European works on medicine. Even if we claim that these defects can be overcome by borrowing from the new works, still they cannot be translated into Turkish quickly because it takes at least ten years to master the Arabic language in addition to five or six years for the study of medicine. And what we need is welltrained doctors for our troops and for our people, on the one hand, and to have the medical literature codified, on the other. Therefore, my purpose in having you study the French language is not to teach you French as such but that you may learn medicine-and in order to incorporate that science step by step into our own language. Medicine will be taught in Turkish in our land only when this has been done. ${ }^{59}$

The Sultan further explained to the students that the school's goal was "to teach you scientific medicine and little by little to take it into our language... work to acquire knowledge of medicine from your teachers, and strive gradually to take it into Turkish and give it currency

\footnotetext{
${ }^{58}$ Ibid., p. 116.

${ }^{59}$ Quoted in Ibid., p. 113.
} 
in our language...."

For the training of bureaucrats, the Sublime Porte established several schools. The palace school (Enderün Mektebi) ${ }^{61}$ and the school of the arts of correspondence (Kitäbet) were established. To train government clerks and administrators, the government set up the School of Literary Science (Mekteb-i Maarif-i Adliye) ${ }^{62}$ in 1838 for selected boys who were preparing for careers as government functionaries. Another school was opened to train government translators, namely, the School of Literary Sciences (Mekteb-i Ulum Edebiye). In these schools, secular subjects were taught alongside religious ones. The students studied Arabic grammar before going on to study French. They also studied geography, geometry, history and political science, as well as Turkish prose. ${ }^{63}$ However, in general the development of effective, secular, modern, civic-sponsored schools was very slow and disappointing. ${ }^{64}$

The modernization of education was enhanced during the Tanzimät (1839-1876), although at first efforts in this direction were not wholly successful. The administrative, financial and professional aspects of education had never been reformed integrally. ${ }^{65}$ A special bill adopting the French system as the model of education in the Ottoman Empire was prepared by a team appointed by a leading Tanzimät politician, Fuat Pasa. During this period, school curricula were westernized extensively. Modernization in public education began with the foundation of the first modern public schools in Istanbul in 18381839, later called mektebleri. It was in these schools that the grade system

${ }^{60}$ Quoted in Lewis, The Emergence, p. 84.

${ }^{61}$ The Palace School or great military school of state of the Grand Seraglio was founded by Muhammad the Conqueror shortly after his conquest of Constantinople. The aim of the school was to produce warrior-statemen and loyal Muslim. See, Barnette Miller, The Palace School of Mubammad the Conqueror (Cambridge: Harvard University Press, 1941).

${ }^{62}$ Despite its name, which was taken from the name of the Sultan who founded it, literature rather than law was the focus of the curriculum.

${ }^{63}$ Somel, The Modernization of Public Education, p. 34; Berkes, The Development of Secularism, p. 106.

${ }^{64}$ Findley, Bureaucratic Reform, p. 159.

${ }^{65}$ Somel, The Modernization of Public Education, p. 51. 
was first introduced into Ottoman education. ${ }^{66}$ The Board of Useful Affairs in 1838 echoed the need for a new form of education that combined both religious and secular subjects. It also proposed establishing a school for adolescents, although this proposal was slow to be realized. It wasn't until two years later, in 1840, that the first such secular school, the Rusdiye, was opened. ${ }^{67}$

In line with the European idea that government should serve wide public responsibilities, Sultan Abdulmecid proclaimed on March 7, 1845 that "ignorance, the source of much evil, should vanish from among the people." ${ }^{\prime 8}$ Following implementation of the legislation known as Hatt-i Humayun in 1845, he formed a committee of seven "men well-versed in the judicial, military, and civil sciences" to evaluate the existing schools and prepare new reformed ones. ${ }^{69}$ In June 1846, an important step towards the secularization of education occurred when the central government established the "Council of Public Education" (Meclis-i Ma'arif-i Umümiye), which was jointly supervised by the head of the Sublime Council for Judicial Ordinance (Meclis-i Vâla-yi Abkäm$i$ Adliye), Sadik Rifat Pasha, and the head of the Ministry of Foreign Affairs, Resid Pasha. This council took charge of controlling education which had previously been under the Office of the Seybülislam. ${ }^{70}$ The committee suggested that the Sublime Porte should establish a system of education that included primary, secondary, and university levels. Permanent Council of Public Instruction was also established. The implementation of this proposal was very difficult, especially in the area of higher education. By the mid-19 ${ }^{\text {th }}$ century, there were only six secondary schools with 870 students, far from the results expected. Once it became clear that the "Directorate for Public Schools" (Mekatib$i$ 'Umumiye Nezareti), a section of the Ministry of the Interior, could not handle the growing scope of education, the government established the Ministry of Public Education (Ma'arif-i Umümiye Nezareti) in $1847^{71}$

\footnotetext{
${ }^{66}$ Ibid., p. 16.

${ }^{67}$ Berkes, The Development of Secularism, p. 112.

${ }^{68}$ Davison, Essays in Ottoman, p. 172.

${ }^{69}$ Lewis, The Emergence, p. 111.

${ }^{70}$ Somel, The Modernization of Public Education, p. 38.

${ }^{71}$ Lewis, The Emergence, p. 112.
} 
to provide and serve state-sponsored education from the primary school to the university level, endorsed by the legislation of $1869 .^{72}$ The ministry was also responsible for supplying teachers to all schools, maintaining their standards, and providing textbooks. ${ }^{73}$ In addition, the Sublime Porte also sent the inspector-general of schools to Europe (particularly England, France and Germany) to study the educational systems there. ${ }^{74}$

The importance of modernization of education was reflected in a speech by the Ottoman vizier, Said Pasa, delivered at about this time:

In order to remedy this situation, first and foremost a serious and powerful effort must be made to improve public education. As long as public education is not disseminated, there will be no leaders capable of directing the internal and external affairs of the Empire soundly, no judges who can administer the public laws justly, no commander who can run the Army efficiently, and no finance officers who can show how to manage and increase the sources of revenue in accordance with economic principles. None of the institutions and operations that serve public prosperity and well being can be brought into existence as long as education is not disseminated. ${ }^{75}$

In the meantime, a new school for all Ottoman subjects, irrespective of religious background, had been opened. Three out of the four graduates who were sent to Vienna in 1846 to continue their study were non-Muslims: one Armenian and two Catholic Greeks. Also beginning in this year the government sponsored a large number of state schools from the primary to university levels. By 1847, the schools, fully subsidized by the government, were offering instruction to 314 Muslims and 95 non-Muslims. ${ }^{76}$

Beginning in 1855, the army established its own system of secular education at the secondary level. Nine army rusdiye schools were established in Istanbul and many more in other parts of the empire. It also established $i^{\prime} d \bar{a} d \bar{l}$ schools in Sarajevo, Erzurum, and

\footnotetext{
${ }^{72}$ Davison, Essays in Ottoman, p. 84.

${ }^{73}$ Shaw and Shaw, The Rise of Modern Turkey, p. 108.

${ }^{74}$ Davison, Essays in Ottoman, p. 172.

${ }^{75}$ Quoted in Lewis, The Emergence, p. 175-6.

${ }^{76}$ Berkes, The Development of Secularism, p. 114.
} 
Bagdad for preparing students to continue to the School of Military Sciences. Gradually, the army established at least one $i^{\prime} d \bar{a} d i$ and a number of rusdiye schools in every district. This provided civilians with access to secular education long before the civilian educational system extended into their communities. After the Crimean War, the army expanded its educational system by establishing the Harbiye secondary school and then established the School of the General Staff (Erkän-i Harbiye Mektebi) as a new advanced school of military science. ${ }^{77}$

During the late Tanzimät period, there were three educational institutions established in Istanbul that later served to prepare the state elite and intellectuals of the Empire. One of them was the School of the Civil Service (Mekteb-i Mülkiye-i Sähāne), which was originally established in 1859 offering courses in law, economics, geography, history, and statistics for young clerks. Originally, the program was of two years' duration, but was expanded to three years in 1869 and finally to four years in 1870 . French became compulsory, while various languages of the Empire such as Greek, Armenian, or Bulgarian could be studied as electives. During the Hamidian period, this school was expanded to the status of a professional college by adding three years of secondary school education ( $i^{\prime} d \bar{a} d \bar{l}$ ) and two years of professional classes to the program. The teachers in this school included some of the most distinguished intellectuals in the Empire, such as Mizānci Murad Bey, Abdurrahman Seref Bey, Skizli Ohannes Pasha, and Akyigitzāde Musā Bey. Rüsdìyye graduates could enter this school after passing an entrance examination, and its graduates had priority access to positions in the Empire's bureaucracy. ${ }^{78}$

The second school developed by the government was the Mekteb$i$ Sultani (currently Galatasaray Lisesi) founded in 1868. Muslims and non-Muslims could attend this school. The curriculum adopted the French lycée curriculum and added local courses such as religion, Ottoman history, Islamic history, the Arabic, Persian and Ottoman Turkish languages and literatures, geography and calligraphy. Other courses included natural sciences, law, philosophy and classical

${ }^{77}$ Shaw and Shaw, The Rise of Modern Turkey, p. 107.

${ }^{78}$ Somel, The Modernization of Public Education, p. 52. 
European languages such as Greek and Latin, which were taught in French. It was originally a five-year high school but subsequently developed into a twelve-year program of education with the inclusion of seven years of primary grade instruction. Instruction was given by French and Ottoman teachers. The high quality of this school enabled the graduates to continue to French universities. In 1874, the government attached three professional schools to it: the Law School (Galatasaray Hukuk Mektebi), the School of Humanities (Galatasaray Edebi Mektebi) and the Engineering School (Turüku Meäbir Mektebi). ${ }^{79}$

The third educational institution developed in the late Tansimat period was the Dárüssafaka ("House of Compassion"), a private orphanage founded in 1873 by the philanthropic organization Cemiyyet$i$ Tedrisiyye-i Islamiyye ("Society for Islamic Education") to promote education among low-income Muslim families. This school was modeled on the military schools and its disciplined environment made it one of the best schools of its time. The instructors were mostly military officers who also prepared textbooks and translated material from French into Ottoman Turkish. Some graduates of this school became distinguished intellectuals, such as the prominent journalist and author Ahmed Rāsim. $^{80}$

The traditional religious schools were replaced by newer, more modern schools that operated on a graded system. The first stage was primary school (sibyan mektebleri). This school was supposedly established in every village. The language of instruction was the local language. The students were taught the Ottoman alphabet and basic reading skills so that they could study Ottoman grammar in the next stage, as long as they passed the exams at the end of each year. The second stage was the rïsdiye mektebleri, or middle schools. These schools were established in every town. The third stage was the idadiye mektebleri, founded in the 1870s. This was a grammar school that lasted for three years where the language of instruction was Turkish. All students lived in a boarding house that was financed by the state. ${ }^{81}$ The quality of

\footnotetext{
${ }^{79}$ Ibid., p. 53.

${ }^{80}$ Ibid., p. 53-4.

${ }^{81}$ Karabinova, "A Late Attempt", p. 244.
} 
the rüsdiye secondary school did not however accord with what had been expected. Many of its graduates could not write in the proper way. The Ottoman administration, therefore, could not benefit immediately from these graduates. To overcome this difficulty, the Ministry of Public Education established a year-long preparatory school for graduates entering on an administrative career. This school was called the Mekteb-i Eklam ("School of Bureaus"). However, this school also proved unsatisfactory, so that the course was expanded to three years and was now named as Mahrec-i Eklam ("Outlet for the Bureaus"). ${ }^{82}$ The poor quality of rüsdiye schools also led to the establishment of an Ottoman school in Paris in 1855. This school was established to prepare Ottoman students to study in high-quality schools in Paris. ${ }^{83}$

The first modern public primary schools, the ibtida'i mektebleri, were established as an alternative to Qur'ān schools, which were proving difficult to reform. ${ }^{84}$ In 1869, the Ottoman government declared the "Regulation of Public Education" (Ma'árif-i 'Umúmiye Nizāmnāmesi), which stated, among other things, that state primary education had to be prioritized. The planning involved was staggering. One rüsdiye school had to be established in every village or town that had at least 500 houses, with separate schools provided for girls and for Muslims and non-Muslims in any heterogeneous community. The schools operated on a graded system of four years' duration. Religious lessons were provided according to the religion of the students. Other subjects included the Turkish, Arabic, and Persian languages, arithmetic and accounting, geometry and mathematics, world and Ottoman history, geography, and the language of the area where the school was located. The graduates of the rïsdiye schools could continue to $i$ 'da $\bar{d} \bar{i}$ schools which had to be provided in towns and cities with the population of at least a thousand households. This school lasted for three years, and students were taught Turkish and French, logic, economics, geography, world and Ottoman history, algebra, arithmetic, accounting,

\footnotetext{
${ }^{82}$ Somel, The Modernization of Public Education, p. 49-50.

${ }^{83}$ Merdin, The Genesis of Young Ottoman, p. 213.

${ }^{84}$ Somel, "Ottoman Islamic Education," p. 443.
} 
engineering, the physical sciences, chemistry and draftsmanship. The graduates of $i$ 'dadi schools could continue to a lycèe or to the Mektebi Sultani (School of the Sultan), which had to be established at least in every provincial capital city. This school charged tuition, so that only students from wealthy families could afford to study in it, while only the very best poor students could attend this school free of charge. ${ }^{85}$ In addition, the Hamidian regime attempted to integrate and centralize all types and levels of education. This was the first serious attempt in the Empire to systematize education and the administration of schools. ${ }^{86}$

An educational administration at the regional level -with all its organs, personnel and procedures- was established in each province. Financing for provincial schools and local educational administrations was also provided. ${ }^{87}$ The regulation also placed religious education under government surveillance with the result that the influence of the ulema on public schools was diminished. A policy of mixed education of Muslims and non-Muslims was also implemented in order to bridge the divide between the communities. ${ }^{88}$

A "new method" of teaching, proposed by Selim Sābit Efendi (1829-1910) in his treatise entitled Rebnüma-i Mu'allimin ("Itinerary for Instructors"), was adopted by the Ministry of Public Education in 1871. The "method" was designed to enable students to read Turkish correctly and to write it accurately. Students were also expected to have sufficient knowledge of the Arabic and Persian languages as well as of geography. (They should be no older than twenty five). The treatise also dealt with students' ages, character, health, relations between teachers, students and parents, educational tools and school libraries, school reports and the system of marking, the keeping of class books, methods of examination and even hygienic conditions. Based on this treatise, the first government primary school (ibtidar

${ }^{85}$ Shaw and Shaw, The Rise of Modern Turkey, p. 108.

${ }^{86}$ Betül Basaran, "American Schools and the Development of Ottoman Educational Policies during the Hamidian Period: A Reinterpretation," in Ali Caksu, International Congress on Learning and Education in the Ottoman World (Istanbul: IRCICA, 2001), p. 188. p. 185-235.

${ }^{87}$ Somel, “Ottoman Islamic Education”, p. 444.

${ }^{88}$ Somel, The Modernization of Public Education, p. 108. 
mektebi) combining religious and practical knowledge was founded in 1872. Students had to wear European-style uniforms, ${ }^{89}$ and received additional instruction in the secular social sciences such as geography, history and politics. ${ }^{90}$

For young boys graduating from the traditional Muslim elementary schools, secondary secular schools (rüsdiye) were opened to provide technical training so that they could become doctors, engineers, etc. However, it took many decades to develop a large educated class. By 1867, less than 3 per cent of the population was enrolled in the new schools. ${ }^{91}$

The Mulkiye school for training civil servants was reorganized and expanded in 1877, particularly the senior classes. The curriculum was revised to include modern subjects. Boarding facilities were provided for students from the provinces. ${ }^{92}$ The Harbiye or War College was maintained and extended, as well as the military and civil medical schools and a few other foundations, such as the artillery, naval and military engineering schools. From 1842 onwards, English became the main foreign language taught, and French became an elective course. ${ }^{93}$ Some individual officials initiated reforms in education in their own jurisdictions. Midhat Pasa, the governor of Danube province in the 1860s, established modernized primary schools with the help of Namik Kemal by consulting references on French provincial school organization. ${ }^{94}$ Of course, the key figure in Sultan Abdulhamid's plans was Mehmed Said Pasha (1838-1914), the son of a diplomat and the descendent of an ulema family. ${ }^{95}$

In 1875 a separate military rüsdiye school was established to prepare students for admission to military high schools and colleges. Sultan Abdulhamid established several other rüsdiye school in the centers of all the 29 vilayets and 6 independent mutasarrifiks of the

\footnotetext{
${ }^{89}$ Ibid., p. 446.

${ }^{90}$ Davison, Essays in Ottoman, p. 171.

${ }^{91}$ McCarthy, The Ottoman Turks, p. 299.

${ }^{92}$ Lewis, The Emergence, p. 177.

${ }^{93}$ Somel, The Modernization of Public Education, p. 21.

${ }^{94}$ Davison, Essays in Ottoman, p. 172.

${ }^{95}$ Lewis, The Emergence, p. 175.
} 
Empire, as well as in many kaza centers. These led to the establishment of idadiye schools, which provided middle and early secondary education, first in Istanbul in 1875, and later (by 1904) in Damascus, Baghdad, Erzincan, Edirne, and Manastir. ${ }^{96}$

The curricula of schools were modified and enhanced with 'secular' subjects. Just as in provincial i'dādi (middle) schools, the typical curriculum included cosmography, general and Ottoman geography, economics, geometry and agricultural science. French language and translation continued to be the main part of Galatasaray school curriculum in addition to lessons in Arabic, Greek, Bulgarian and Armenian. ${ }^{97}$ In the Hamidian period, however, the Galatasaray school became more Turkish. Latin was dropped from the curriculum and the proportion of Turkish students increased. The school became more and more the preferred destination for the sons of the ruling classes and the landowning, military, and bureaucratic families of the capital. ${ }^{98}$

A rüsdiye school for girls was established for the first time in 1858. The Tan:imat reformers added a few schools for girls, women's training colleges (the Female Teachers' Seminary produced graduates for the first time in 1873) and art schools. However, such schools continued to stereotype women by offering courses mainly on religion and practical skills such as handicrafts and sewing that would enable them to provide comfort to their husbands in the home while helping them to preserve their honor. ${ }^{99}$ Meanwhile, women of the higher classes of society had always have enjoyed access to good, private education. ${ }^{100}$

The attempt to revise the curriculum so that it was more compatible with Islamic norms and values was an initiative of Sultan Abdulhamid II. The reform consisted mainly in adding various courses on agriculture and crafts and increasing the number and duration of courses on religion and ethics. ${ }^{101}$ In 1899 , a commission to inquire into the quality and quantity of schools in the Empire was formed. Its

\footnotetext{
${ }^{96}$ Ibid., p. 178.

${ }^{97}$ Deringil, The Well-protected Domains, p. 98.

${ }^{98}$ Lewis, The Emergence, p. 178.

${ }^{99}$ Somel, The Modernization of Public Education, p. 57.

${ }^{100}$ Lewis, The Emergence, p. 225.

${ }^{101}$ Basaran, "American Schools", p. 196.
} 
members, who included the Minister of Foreign Affairs Tevfik Pasa, the Minister of Education Zuhdu Pasa, and the Director of the Bureau of Secondary Schools Celal Bey, proposed that modern primary schools for all religious communities in the Empire and institution-schools for orphans be urgently established. In the six eastern provinces including Erzurum, Sivas, Van, Bitlis, Mamuretu'l-aziz and Diyarbekir, there were about 6,331 non-Muslim orphans and about the same number of Muslim orphans. If the government could provide sufficient schools for the orphans, they noted, the missionary influences on orphans would be reduced. ${ }^{102}$ Another suggestion from the committee was to establish schools for crafts (sanayi mektebleri) so as to prepare students to earn a living, while at the same time preventing foreigners and non-Muslims from acquiring a monopoly over such skills. An added advantage would be that fewer Ottoman subjects would travel abroad to study. The school was initially established under the Tanz̧imàt regime, and Sultan Abdulhamid continued this effort by establishing a commission for the promotion of handicrafts, so that new schools were opened in Istanbul, Edirne, Adana, Izmir, Baghdad, Bursa, Aleppo, Salonika, Damascus, Kastamonu, Kosova, Sivas, Tripoli, Yemen, Beirut, Manastir and Erzurum. There were also three craft schools for girls established in Istanbul and others in Damascus and Tripoli. ${ }^{103}$

The modernization of education also spread to the Ottoman provinces. In Bosnia, for example, modern versions of the rüsdiye were established in 1853 . There were 12 such schools at the beginning. The subjects taught included Turkish, Arabic, Persian, the history of the Ottoman Empire, geography, arithmetic, geometry, composition, drawing, gymnastics and religion. In Sarajevo, the Sabah-Mekteb, a school for educating civil servants, established by Topal Osman Pasha (18601869), offered courses in arithmetic, history, geography, Arabic, Turkish, Persian, and Bosnian. In 1863, a school called the Därül Muallimin, dedicated to preparing teachers, was established also in

${ }^{102}$ Ibid., p. 194.

${ }^{103}$ Ibid., p. 195. 
Sarajevo, where secular subjects were taught. ${ }^{104}$ The Higher Teachers' Seminary (Därülmuallimin-i Áliyye), which operated in 1891-1892, likewise had its origins in the Tanzimat period. ${ }^{105}$ The curriculum of this school contained secular and religious subjects such as arithmetic, history, geography, agriculture, French and methods of instruction, as well as the Qur'an, Islamic precepts and religious sciences, and the Arabic and Turkish languages. ${ }^{106}$

The government also established several elementary secular education and artisan training schools for orphans (islabhanes, or reform school) and poor boys (sanayi mektebis, or industrial schools). These schools contributed to the development of Ottoman industry. At the lycèe level, a trade school for adults and the Naval School (Babriye Mektebi) were established in 1870 for training officers in the merchant marine. ${ }^{107}$

\section{E. Conclusion}

The modernization of the educational system in the Ottoman Empire in the nineteenth century was triggered by many factors. The backwardness of the religious educational system that dominated the system of education prior to this century became the main spur to the modernization. The outdated curriculum, methods, and management of the system in place had led in turn to the backwardness of the Ottoman government and society, which were then unable to compete with increasingly powerful neighboring countries. External factors also contributed to the push towards modernization. The advancement of educational systems in Western countries and Russia, which led to their military superiority vis-à-vis the Ottomans, triggered an effort to catch up in this domain. This is why the modernization of education was initially focused on enhancing the ability of the Ottoman military to face foreign armies. The development of schools that benefited the

${ }^{104}$ Azra Gad•o-Kasumovi , "Education-Beginning and Development of the Ottoman-Islamic Literacy in the Bosnian Eyalet", in Ali Caksu, International Congress on Learning and Education in the Ottoman World (Istanbul: IRCICA, 2001), p. 215-6.

${ }^{105}$ Somel, The Modernization of Public Education, p. 131.

${ }^{106}$ Ibid., appendix 9.

${ }^{107}$ Shaw and Shaw, The Rise of Modern Turkey, p. 111. 
army led to the development of civil secular education in order to enhance social and economic development in the Empire. Secular knowledge and practical skills were introduced in the new schools. Western-type schools were developed widely so that the Ottoman subjects could advance socially and economically, keeping step with people in Western countries. The development of non-Muslim minority schools modeled on Western schools also spurred the Ottoman government and Muslim population to compete with their non-Muslim counterparts. This was enhanced by the fact that the economic and social achievements of many non-Muslims seemed higher than that of Muslims. In addition, advances in educational theory and policy in European nations had an impact on the modernization of education in the Ottoman Empire.

The modernization of the educational system was a long process. It was initiated as early as the mid-eighteenth century with the introduction of a school of mathematics. Various military secular schools were established to enhance the performance of the Ottoman military, which had been left behind by the military forces of neighboring countries. Ottoman military technology did not develop due to the backwardness of its educational system. A naval school and a military engineering school gave impetus to the modernization of education in other fields. The later development of schools was also due, at first, to the need to enhance Ottoman military performance. Schools of engineering and medicine were initially for the purpose of military development. The modernization effort then spread to the training of a modern Ottoman bureaucracy. The palace school, the school of the arts of correspondence, and the school for literary sciences were established for the development of more effective and efficient Ottoman bureaucracy. The acceleration of the modernization of education system was also due to the efforts of many reformed Ottoman intellectuals and politicians. They were assisted by a number of Western scholars especially from France, and later Germany and Britain. Meanwhile, the modernization of primary and secondary education became a priority when it was realized that the poor quality of religious education could not supply graduates able to meet the entrance requirements at higher levels of secular education. Initially, 
Lathiful Khuluq

many educational institutions developed their own preparatory schools in order to meet the standards of education that they required. Then, the Ottoman government, through its administrative apparatus, attempted to integrate the modernization of the educational system from primary to university level. This effort was not fully successful as many religious educators opposed to modernization. In addition, the change in educational philosophy during the Hamidian period, with its emphasis on Islamic morality and discipline as well as Ottomanism and Islamism also slowed down the secularization of the educational system that had been initiated during the Tanzimät period. 


\section{BIBLIOGRAPHY}

Babinger, Franz, Mebmed The Conqueror and His Time, Trans. Ralph Manhein, Princeton, N.J.: Princeton University Press, 1978.

Basaran, Betül, "American Schools and the Development of Ottoman Educational Policies during the Hamidian Period: A Reinterpretation," in Ali aksu, International Congress on Learning and Education in the Ottoman World, Istanbul: IRCICA, 2001, pp. 185-235.

Berkes, Niyazi, The Development of Secularism in Turkey, Montreal: McGill University Press, 1964.

Davison, Roderic H, Essays in Ottoman and Turkish History, 1774-1923: The Impact of the West, Austin: University of Texas Press, 1990.

Deringil, Selim, The Well-protected Domains. Ideology and the Legitimation of Power in the Ottoman Empire 1876-1909, London \& New York: I.B. Tauris, 1998.

Findley, Carter V, Bureaucratic Reform in the Ottoman Empire: The Sublime Porte, 1789-1922, Princeton, New Jersey: Princeton University Press, 1980.

Fortna, Benjamin C., Imperial Classroom: Islam, State, and Education in the Late Ottoman Empire, Oxford; New York: Oxford University Press, 2002.

Gad•o-Kasumovi , Azra, "Education-Beginning and Development of the Ottoman-Islamic Literacy in the Bosnian Eyalet", in Ali aksu, International Congress on Learning and Education in the Ottoman World, Istanbul: IRCICA, 2001, pp. 215-16.

$\mathrm{G}$ çek, Fatma Müge, Rise of the Bourgeoisie, Demise of Empire: Ottoman Westernization and Social Change, New York and Oxford: Oxford University Press, 1996.

Greenwood, Keith M., Robert College: The American Founders, Istanbul: Bogaziçi University Press, 2000.

Inalcik, Halil., The Ottoman Empire. The Classical Age 1300-1600, Trans.

Norman Itzkowitz and Colin Imber, London: Weidenfeld and Nicolson, 1973. 
Karabinova, Diana, "A Late Attempt to Find an Integrative Approach Through Common Secular Education: Midhat Pasa as Governor of the Danube Province (1864-1868)," in Ali aksu, International Congress on Learning and Education in the Ottoman World, Istanbul: IRCICA, 2001. pp. 237-246.

Kazamias, Andreas M., Education and the Quest for Modernity in Turkey, London: George Allen \& Unwin Ltd., 1966.

Lewis, Bernard, The Emergence of Modern Turkey, London, New York, Toronto: Oxford University Press, 1961.

Lyber, Albert Howe, The Government of the Ottoman Empire in the Time of Suleiman the Magnificent, Cambridge: Harvard University Press, 1913.

McCarthy, Justin, The Ottoman Turks. An Introductory History to 1923, New York: Addison Wesley Longman, 1997.

Merdin, Serif, The Genesis of Young Ottoman Thought: A Study in the Modernization of Turkish Political Ideas, Princeton, New Jersey: Princeton University Press, 1962.

Murphy, R., "Yeni Ceri" In The Encyclopaedia of Islam, New Edition, Vol. XI. Leiden: Brill, 2001, pp. 322-331.

Palmer, Alan, The Decline and Fall of the Ottoman Empire, New York: M. Evans and Company, Inc., 1992.

Parla, Taha, The Social and Political Thought of Ziya Gokalp, 1876-1924, Ph.D. Thesis at Columbia University in 1980, Ann Arbor, Michigan, London, England: University Microfilms International, 1982.

Shaw, Stanford J., and Ezel Kural Shaw, History of the Ottoman Empire and Modern Turkey, Volume II: Reform, Revolution, and Republic: The Rise of Modern Turkey, 1808-1975, Cambridge: Cambridge University Press, 1977.

Sicker, Martin, The Islamic World in Decline. From the Treaty of Karlowitz. to the Disintegration of the Ottoman Empire, Westport, Connecticut, London: Praeger, 2001.

Somel, Selçuk Aksin, "Ottoman Islamic Education in the Balkan in the Nineteenth Century," Islamic Studies 36:2, 3 (1997). 
--------, The Modernization of Public Education in the Ottoman Empire 1839-1908: Islamization, Autocracy and Discipline, Leiden, Boston, $\mathrm{K}$ ln: Brill, 2001.

Pallis, Alexander, In the Days of the Janissaries, London: Hutchinson and Co., 1951.

van Os, Nicole A.N.M., "A Nation whose Women are living in Ignorance...": The Foundation of the Milli Inas Mektebi in Nisantasi" in Ali aksu, International Congress on Learning and Education in the Ottoman World. Istanbul: IRCICA, 2001. pp. 247258.

Zorlu, Tuncay, "The Medical Medrese of Süleymaniye," in Ali aksu, International Congress on Learning and Education in the Ottoman World, (Istanbul: IRCICA, 2001), pp. 63-87. 